\title{
Determinant of Indonesian Stock Market's Volatility During the Covid-19 Pandemic
}

\author{
Ainine Devara Nugroho ${ }^{1}$, Robiyanto Robiyanto ${ }^{2 *}$ \\ 1,2Department of Management, Faculty of Economics and Business, \\ Satya Wacana Christian University, Indonesia \\ *Corresponding Author: robiyanto@staff.uksw.edu
}

\begin{abstract}
The aim of this study is to examine variables that influenced the Jakarta Composite Index (JCI) volatility during the outbreak of COVID-19. The independent variables that are used are gold return volatility and USD/IDR return volatility. This analysis uses daily-time series data which are divided into three periods, those are; before the pandemic (January 2019-August 2019), during the pandemic (January 2020-August 2020), and from January 2019 through August 2020. The method that is used in this study is GARCH analysis in order to dodge data abnormality and heteroscedasticity. Before conducting GARCH analysis, unit root and normality test are conducted to know if the data are stationaries and to decide which GARCH distribution is the most suitable for the data analysis (Gaussian, t-student, or GED distribution). It is proven in this study that during the COVID-19 pandemic, gold return volatility positively affected the JCI volatility and USD/IDR volatility negatively affected JCI volatility. This research can be used as a consideration for investors in choosing their investment during the pandemic or financial crisis by examining gold and USD/IDR volatility effect on JCI volatility.
\end{abstract}

\section{Keywords : COVID-19; GARCH; Gold; JCI; USD/IDR; Volatility JEL Classification : G01, G32}

\section{INTRODUCTION}

In the early of 2020, the world was shocked by an infectious disease namely 2019$\mathrm{nCoV}$, or we call it as COVID-19. The very first case was found-in Wuhan, the capital of China's Hubei province in December 2019, and was identified by the WHO China Country Office as pneumonia of unknown etiology. In January 2020, WHO has asked the national authorities of China to give further information about the risk of this disease, but the outspread happened so fast and affected almost all countries in the world. Considering that there will be a serious problem that might occur, the WHO Director General, under the International Health Regulations (IHR), held a meeting of the Emergency Committee and declared the 2019-nCoV outbreak as a Public Health Emergency of International Concern (PHEIC) (World Health Organization, 2020).

The outspread of COVID-19 was not only affecting the entire world's health, but also the economy of the world. As we know, almost all countries started to strictly adopt 
quarantine policy in which the societies were appealed to stay at home. Therefore, many industries had to stop their production in order to obey the government's regulation and protect their employees. As a consequence, the economic activities were hampered. And in the long-term, the outbreak of COVID-19 will cause business bankruptcies and a largescale of employee layoff (Zhang et al., 2020). According to Sansa (2020), COVID-19 outbreak will lead to the global recession, it will cause more severe economy problem compared to the 2008 Subprime Mortgage. Indonesia could not escape from the losses caused by the COVID-19 outbreak as well. As we know that Indonesia and China have close trade relations, thus Indonesia was also experiencing an economic slump where its export and import activities, tourism sector, and investment were decreasing (Nia, 2020). Moreover, when the government confirmed the first COVID-19 case of Indonesia on March, 2 2020 and started promoting work and study from home, the economy of Indonesia became chaotic. Businesses started to fail, and many people lost their job.

As we know, the economy of the world was in confusion during the COVID-19 outbreak, and indirectly affect the financial markets. Many studies were conducted to find out the impact of COVID-19 pandemic towards the stock markets in the world, and most of them only focused on stock market return, they approved that there is a significant effect between stock market and the COVID-19 outbreak. Shanghai Stock Exchange (SSE) and Shenzhen Composite Index (SZSC) in China was surely experiencing a decline. Even SZSC has dropped by $-8.45 \%$ (Nia, 2020). The stock market index of USA, The Dow and S\&P, reported a fall by $-20 \%$, as well as Nikkei, the stock market index for the Tokyo Stock Exchange (Sansa, 2020). Other than that, FTSE (UK) also dropped by $10 \%$ on March, $12^{\text {th }} 2020$, and Colombo Stock Exchange had fallen by $-9 \%$ and was forced to close the trading 3 times during that time (Sansa, 2020; Zhang et al., 2020).

Meanwhile, there are many factors which can determine the volatility of stock market throughout this pandemic. Nia (2020) stated that in the globalization era nowadays, all countries in the world are more integrated and interdependent, especially in the economy sector. An issue in one financial market will affect the movement of the other markets. It is supported by Vahlevi and Muharam (2017) statement that stock market index, interest rate, commodity index, and exchange rate can be used to measure the financial market volatility. But until this research was completed, there were still a few studies conducted to measure the stock market volatility using its relation towards the other financial markets during the COVID-19 outbreak, especially in Indonesia. For instance, Baker et al., (2020) only analyzed how COVID-19 affect the US stock market volatility. Same with Sansa (2020), the analysis was done by using the confirm cases of COVID-19 as the independent data, and China and US stock return as the dependent data. While in Indonesia, Nia (2020) only analyzed the stock market Indonesia during the COVID-19 pandemic using its closing price, stock's circulation, interest rate and book value of equity. Therefore, this research intends to measure the stock market volatility of Indonesia which is proxied by Jakarta Composite Index (JCI) using its relation towards the USD/IDR exchange rate and gold price from January 2019 to August 2020 in order to know the relation between each variable before and during COVID-19 spreads.

Exchange rate and gold price are considered as the representatives of macroeconomic conditions. And based on Surbakti et al (2016) macroeconomic conditions may influence the volatility of stock market, since it influences the firm's daily operations. Wahyudi et al (2017) also has the same idea where stock market fluctuation is indivisible from the macroeconomic conditions (i.e. exchange rate and gold price). The changing in 
exchange rate and gold price can cause stock uncertainty. Abd Rahman \& Ramli (2013); Kalu and Okwuchukwu (2014); Kirui et al (2014); Rashid Sabri (2004) approved that there is a significant effect between stock volatility and exchange rate. Apart from that, Baur \& Lucey (2010) conducted a study regarding gold, stocks and bonds in US, German and UK. They found that gold can be a stock's safe haven in three countries only during the extreme financial market decline at a short period of time. This result is in line with Baur \& McDermott (2010) which explained that gold acts as a panic buying of investors in the financial market shocks.

In the pandemic situation as it is now, the economy is in hesitation along with uncertainty in the financial market which will cause a high risk. Thus, this research is expected to help the investors and traders to understand the determinant of stock market volatility and can be their additional information in knowing the effect of volatility on the stock market price during pandemic, in order to get the right and advantageous investment decision and also to reduce risks. This research will be beneficial for the policy makers as well, since it helps them to know and understand the factors that can determine the stock market volatility. Other than that, this research is aimed for the next researchers to conduct the next study.

\section{HYPOTHESIS DEVELOPMENT}

\section{COVID-19 Pandemic}

COVID-19, also called as Coronavirus, is a non-segmented RNA virus which is included in the family Coronaviridae. This disease is originated from Wuhan, the capital of China's Hubei province (Huang et al., 2020). Based on the media report, on January, $1^{\text {st }}$ 2020, the market in Wuhan that was suspected to be the emergence area of COVID-19 was closed for environmental sanitation and disinfectant enforcement. No longer than January, 13 th 2020, Thailand was reported as the first case of COVID-19 outside China. And since then, people that were infected by COVID-19 kept increasing (World Health Organization, 2020). The total of confirmed cases in the world until May 2020 is 4.71 million cases with 1.73 million recovered cases and 315 thousand death cases. While up to May, 25 2020 Indonesia had 22,750 positive cases, with 1,391 death cases and 5,642 patients that has recovered (WHO South-East Asia, 2020).

This pandemic has impacted so many sectors, and its impact has been escalating since WHO declared COVID-19 as a Public Health Emergency of International Concern (PHEIC). Before the COVID-19, such outbreak like Middle East Respiratory Syndrome (MERS) and Severe Acute Respiratory Syndrome (SARS) were once a concern for the world, but the impact was not as big as the COVID-19 outbreak (Senol and Zeren, 2020). However, WHO committees believe that there is still a way to prevent the spreading of this virus, they suggest each country to start providing its health department with strong measure equipment to detect the disease early on, encourage its society to practice physical distancing, isolate and medicate the cases according to SOP and trace contact (World Health Organization, 2020). This suggestion has been followed by many countries including Indonesia since March, 19th 2020.

\section{Stock Market Volatility}

In the financial market, volatility is one of the critical concepts. it can help the traders and investors examine the possible profit and loss of a certain security. Volatility itself can be defined as the statistical measurement of security's return or commodity price spreading at the particular time. The volatility of a security is often measured by 
calculating its return's standard deviation or variance (Surbakti et al., 2016). Thus, it can assist the traders and investors in predicting the security's value uncertainty for both near and distant future.

When a security has a higher volatility, it means that the security's value is widely dispersed. It will cause the security's value to change straight away in each direction at a short period of time. While if a certain security has a lower volatility, it means that the security's value tends to be more stable. Volatility can be disadvantageous for some traders or investors since they may not gain the expected return at a time which they look forward to. But for some investors, security with high volatility can be beneficial as well, since the chance to get prominent capital gain is higher. Yet with this preference, the investors also have to face a higher risk as the security's value uncertainty is greater. Nevertheless, investors will only take that risk if there is surely big probability in gaining higher profit, or what so-called high risk, high return (Handayani et al., 2018).

In Indonesia itself, stock market has developed well. Issuers and investors in Indonesian Stock Exchange (IDX) are increasing and it gives a good influence to the value and volume of trading in IDX. This positive growth attracts the foreign investors and global financial organizations to start-off their investment and transaction on IDX. This condition causes a positive impact to the capital market since it gives capital inflows. But at the same time, it will cause a volatility in IDX since global financial organizations and foreign investors are types of investors that are sensitive to the global financial market's changes (Robiyanto et al., 2017). Thus, when a country, in this case is Indonesia, is experiencing a crisis or economic problem, foreign investors will tend to withdraw their investments from IDX.

\section{Jakarta Composite Index}

As the name suggests, Jakarta Composite Index (JCI), also known as IDX composite, is a composite index of all stocks that are traded in Indonesia Stock Exchange (IDX). It was first known in April, 1st 1983. While the calculation basis day was in August 10 1982 with thirteen stocks and basis value of one hundred. When the JCI increases, it means that the Indonesian stock market is in a very good situation and when it decreases, that means the Indonesian stock market experiences a shrinkage (Robiyanto, 2018). This statement is supported by Adam (2014) who said that JCI's dynamic shows the performance indicators of industries which sell their stocks in Indonesian Stock Exchange (IDX). Based on this reason, JCI is the best variable to proxy the stock market volatility in Indonesia during COVID-19 pandemic for this research.

There are many studies conducted mainly to discuss the impact of COVID-19 to the stock market in the world, and most of them only focused on the stock return. Sansa (2020) and Zhang et al., (2020) confirmed that COVID-19 caused a price depreciation in the stock market. Al-Awadhi et al (2020) confirmed that COVID-19 had a negative significant effect towards Shanghai Stock Exchange (SSE) return even though some of index sectors (such as: information technology and medicine manufacturing stock return) were experiencing a minor improvement. Liu et al (2020) conducted the same research for the other 21 countries that were affected by COVID-19 and approved that this outbreak affects the stocks return. Furthermore, Nia (2020) stated that at the end of January 2020, JCI experienced $4.87 \%$ decline and $-8.52 \%$ in February 2020. The other evidences from other countries' index, such as; Dow Jones (-26\%), DAX (-29\%), S\&P500 (-24\%), NIKKEI225 $(-23 \%)$, FTSI100 (-29\%), Shanghai $(-10 \%)$, and Nasdaq $(-18 \%)$ were also 
experiencing a decline between January to April 2020 and kept decreasing as WHO reported COVID-19 as global pandemic in March 2020 (Senol and Zeren, 2020).

\section{Exchange Rate}

Exchange rate is the value of one country's currency compared to another country's currency. Principally, there are two types of exchange rate system, first is the fixed exchange rate where the central bank of a country sets the price of its currency. While the second one is the floating exchange rate where the price of a currency depends on the supply and demand in the market. According to Robiyanto (2018), Indonesia has implemented the free-floating exchange rate since August, 14th 1998. and free-floating exchange rate itself can cause uncertainty, since the USD/IDR exchange rate depends on the supply and demand in the forex market.

COVID-19 outbreak has impacted the exchange rate in almost all countries, including in Indonesia, Nia (2020) reported that the foreign exchange of Indonesia dropped by IDR54.8 trillion since China flights being temporary closed and also there was tourist restriction from China. Other than that, Chandra (2020) stated that Central Bank of Indonesia forecasted the worst scenario of USD/IDR exchange rate that might fall into IDR17,500 - IDR20,000 per USD. This forecast was in line with Naryono and Sukabumi's (2020) argumentation where in March 2020, the USD/IDR exchange rate almost hit IDR17,000 per USD.

The exchange rate's impact on stock market can be positive or negative. According to Robiyanto et al (2019), the devaluation of country's currency can be a positive impact for the export countries since it can improve the export competitiveness and thus make the stock market of a country becomes attractive. And yet, if the exporters have debt in dollars or import its raw materials, they have to pay more money due to currency depreciation and make the profit decrease which causes a negative impact towards the stock price, this explanation is also approved by Wahyudi et al (2017).

While during the crisis situation as COVID-19 outbreak, the economy of the world tends to be unstable, especially in an emerging country. Financial turmoil that is experienced by a country, in this case Indonesia, will depreciate the domestic currency. The depreciation of IDR also portrays the bad condition of Indonesia's economy, which makes the stock market to be at risk (Robiyanto et al., 2019). Therefore, this condition will influence foreign investors to withdraw their investment, causing shrinkage of stock market capital inflow which leads to the stock market volatility (Pantas et al., 2019). According to Olweny and Omondi (2011), foreign exchange rate has an effect toward the stock return volatility. This statement is in line with Pinjaman \& Aralas (2015) result where exchange rate has a positive relation with the stock market volatility. Kalu \& Okwuchukwu (2014) conducted a study on the relation between exchange rate and stock return volatility in Nigeria and found that exchange rate and stock return volatility have a positive effect. In Indonesia itself, Surbakti et al (2016) conducted a study on global economic crisis in 2008 and also found that exchange rate has a positive effect on JCI's return volatility. It means that the more foreign exchange rate increases (IDR depreciate), the more volatile the local stock market will be, but at the same time it will decrease the US stock market volatility (Walid et al., 2011). Thus, based on the explanation above, the hypothesis is formulated as below:

$\mathbf{H}_{1}$ : USD/IDR exchange rate volatility has a positive impact towards Jakarta Composite Index volatility during COVID-19 outbreak in Indonesia 


\section{Gold Price}

Gold is a durable and valuable metal which can be stored and retrieved at a desired time, expecting that it still has value. It is one of the chemical elements with high atomic number (79) which is also known as Aurum ( $\mathrm{Au})$ in the periodic table. Since gold is considered as a precious metal, it is traded in futures market and commodity market in the form of bullion or gold bars with various weights (usually grams and kilograms) or can be used as a monetary asset (Robiyanto, 2018).

Just like stock market and foreign exchange market, most items in commodity market during COVID-19 pandemic were also experiencing a disruption. Senol and Zeren (2020) reported that, the overall on March 2020, the world primary commodity price decreased by $37.3 \%$. But it also stated that during that time, precious metals sector raised by $5 \%$. Furthermore, Karali and Power (2010) informed that the demand of oil during this COVID-19 outbreak fell down while the demand of gold increased. This information is supported by the decline of the oil price index by $56.30 \%$ and the increase of the gold price index by $26.38 \%$.

Gold can be very beneficial since it can act as a safe haven and also can be used as hedging tactic in the commodity contract (Hussin et al., 2013; Temmuz and Oma, 2012). This statement is in line with Surbakti et al (2016) explanation where gold can be a beneficial investment since it is very liquid, accepted by any region, and the price tends to rise. Ibrahim and Baharom (2011) conducted a study about other possible investments during financial turmoil which cause stock market volatility and found that gold can be an alteranative investment since it can reduce the portfolio investment risk. According to Cohen and Qadan (2010), investors still consider gold as a 'protection' against the stock market variability. It provides hedging towards the stock market risk and a safe haven troughout the ultimate stock market slump. Assets for a hedging investment mostly have a negative relation or are unrelated with the other asset or portfolio, whereas safe haven assets are unrelated or have a negative relation toward the other asset during market turmoil (Miyazaki and Hamori, 2013). In reference to the explanation above, the hypothesis is formulated as below:

$\mathbf{H}_{2}$ : Gold price volatility has a negative impact towards Jakarta Composite Index volatility during COVID-19 outbreak in Indonesia

\section{METHOD, DATA, AND ANALYSIS}

\section{Data}

In this study, the researcher will analyze the data and prove the existing hypothesis by explaining the relation of the independent variable towards the dependent variable or what so-called as associative research (Putra and Robiyanto, 2019). As discussed earlier in the previous chapter, this study intends to know the relation of exchange rate and gold price towards Jakarta Composite Index volatility. This research uses secondary data, which is also classified as quantitative data, where USD/IDR exchange rate data are obtained from Bank Indonesia website (www.bi.go.id), whereas gold price and JCI data are gained from yahoofinance.com. The researcher will use time-series data which are collected from January 2019 to August 2020 in daily basis in order to examine the connection between variables before and during the COVID-19 outbreak in Indonesia's economy and how those variables react to this pandemic.

The test will be conducted three times, consisting of; before the pandemic (using January 2019 to August 2019 data), during the pandemic (using January 2020 to August 
2020 data), and combination of before and during the pandemic (January 2019 to August 2020). For the data of during the COVID-19 pandemic, the researcher chose to take January 2020 as the starting month because even though there was still zero people in Indonesia that got infected by COVID-19, January 2020 was the first month where COVID-19 started significantly affecting almost every country in the world, and since the economy in this era has been more globalized and linked with each country in the world, therefore, any economy disruption happened in one country can affect the other countries' economy (Nia, 2020). Zhang et al (2020) also added that although the outbreak of COVID-19 impact on global economy is still uncertain, financial markets have already become volatile. While August 2020 is chosen to be the final month of the analysis since during the time this research was being conducted, the global COVID-19 crisis was still in play and the market normality has not been recovered yet.

\section{Definition of Operational Variables}

This research uses one dependent variable that is JCI stock return volatility, and two independent variables which are USD/IDR exchange rate and gold price. These variables will be calculated in daily basis.

1. To determine the JCI's volatility, JCI stock return must be calculated. Which can be obtained using this formula:

$$
R_{J C I_{(t)}}=\left[\frac{J C I_{(t)}-J C I_{(t-1)}}{J C I_{(t-1)}}\right]
$$

Where $R_{J C I_{(t)}}$ is the representation of JCI stock return at t-day, $J C I_{(t)}$ is the symbol of JCI closing price at $\mathrm{t}$-day, and $J C I_{(t-1)}$ is $\mathrm{JCI}$ closing price of the previous $\mathrm{t}$-day

Afterward, conditional variance will be used to measure the conditional volatility of the JCI's stock return. According to Daly (2011), conditional variance can measure and forecast the conditional volatility of a return accurately since this model relies on the previous period. This statement is in line with Engle's $(1982,1983)$ result, where big and small fallacy tend to arise in cluster, which proposed a heteroscedasticity form where the forecast of fallacy variance depend on the past disruption. Thus, ARCH model was invented which makes use of general statistical characteristic or what socalled conditional variance.

2. USD/IDR exchange rate will be calculated using USD/IDR exchange rate changes which will be represented as $\Delta E R_{(t)}$, and can be derived using this formula:

$$
\Delta E R_{(t)}=\left[\frac{E R_{(t)}-E R_{(t-1)}}{E R_{(t-1)}}\right]
$$

Where $E R_{(t)}$ is a symbol for USD/IDR exchange rate at $\mathrm{t}$-day, and $E R_{(t-1)}$ is a symbol for USD/IDR exchange rate of the previous t-day

3. Gold price variable will be calculated using gold price changes which will be symbolized as $\Delta$ Gold $_{(t)}$, and can be gained using this formula:

$$
\Delta \operatorname{Gold}_{(t)}=\left[\frac{\operatorname{Gold}_{(t)}-\operatorname{Gold}_{(t-1)}}{\operatorname{Gold}_{(t-1)}}\right]
$$


Where $\operatorname{Gold}_{(t)}$ represents gold price at t-day, and $\operatorname{Gold}_{(t-1)}$ is gold price a day before $\mathrm{t}$ day.

\section{Technique of Analysis}

JCI's volatility is used as the dependent variable in this research. Therefore, stock market volatility must be measured and will be represented by conditional variance. Theoretically, volatility is measured either using the variance or standard deviation which have a crucial laxity since the variance of financial data is changing continuously (Pinjaman \& Aralas, 2015). Karmakar (2005) argues that volatility is not constant over times, he stated that in conducting financial market research, volatility clustering is indicated by the time-series data (e.g. exchange rate and stock return). Volatility clustering itself is introduced by Mandelbrot which means that large shift will be followed by large shift and vice versa. And this indicates that volatility is not randomly changing (Pandey, 2005).

Thus, based on the reason above, R. F. Engle (1983) generated a method called Auto-Regressive Conditional Heteroskedasticity (ARCH) which became the milestone of dynamic volatility estimation method. It is a fundamental econometric method that can be used to predict and approximate the volatility of asset return. The parameters number of $\mathrm{ARCH}$ (q) model in measuring the volatility of asset return really relies on the lags number. The problem with this method is that the higher the lags number $(q)$ increases, the lower the model accuracy will be. Thus, due to the ARCH model's shortcoming, Generalized Auto-Regressive Conditional Heteroscedasticity (GARCH) model was advanced by Bollerslev (1986) in order to catch more long lagged effects with less parameters and the conditional variance. Moreover, GARCH model can be used for a research which has data abnormalities and heteroscedasticity issue (Putra \& Robiyanto, 2019).

Therefore, based on the explanation above, this research will be conducted using $\mathrm{GARCH}$, and conditional variance will represent the measurement of stock market volatility. The research model according to $\operatorname{GARCH}(\mathrm{p}, \mathrm{q})$ can be formulated as below:

$$
V_{J C I}=\beta_{0}+\beta_{1} E R_{t}+\beta_{2} \text { Gold }_{t}+\sigma_{t}^{2}+\varepsilon_{t}
$$

With:

$\varepsilon_{t}=\phi_{t} \varepsilon_{t-1}+\cdots+\phi_{t} \varepsilon_{t-p}+\eta_{t}$

$\eta_{t}=\sigma_{t} \epsilon_{t}$

Where, $V_{J C I}$ represents the dependent variable, that is JCI's volatility. While $E R$ and Gold represents the independent variables, which are USD/IDR exchange rate and gold price. And, $\varepsilon$ is a symbol for error. While, $\epsilon_{t}$ is the clear noise or stationery which selfdetermined and uniformly distributed. It is autonomous to prior error from $\eta_{t-1}$.

While the conditional variance formula will be:

$$
\sigma_{t}^{2}=\alpha_{0}+\alpha_{1} \varepsilon_{t-1}^{2}+\cdots+\alpha_{p} \varepsilon_{t-p}^{2}+\lambda_{1} \sigma_{t-1}^{2}+\cdots+\lambda_{q} \sigma_{t-q}^{2}
$$

Where, $\alpha_{1} \varepsilon_{t-1}^{2}$ is the ARCH symbol of the prior period's volatility and $\lambda_{1} \sigma_{t-1}^{2}$ is the GARCH term for the volatility in the prior period.

In order to conduct GARCH analysis, unit root test must be performed first to know whether the time-series data are stationaries (do not have unit root). Unit root test will be 
done by using Augmented Dickey-Fuller (ADF) test. The data or variables will be accepted if they are stationaries. The ADF result will be tested with the critical value $(\alpha)$ with the value of 0.01 . If the $\mathrm{ADF}$ result has a lower value than $\alpha$, thus it can be concluded that the time-series data are stationaries and the researcher can conduct the GARCH analysis (Kishor \& Singh, 2016).

\section{RESULTS}

\section{Descriptive Statistic}

The purpose of doing the descriptive statistics analysis is to find the minimum, maximum, mean, and standard deviation of all variables used in this analysis. It is shown in the Table 1 below that before the pandemic, JCI return has a lower average $(0.0207$ percent) compare to USD/IDR return (0.1986 percent) which makes USD/IDR has higher return than JCI. However, even though USD/IDR has higher return than JCI, it is shown in the table that USD/IDR has a lower risk compare to JCI as the USD/IDR return standard deviation (0.009787) is lower than JCI return (0.009871). Furthermore, it is stated in the table as well that before the pandemic, the average of gold return is -0.0183 which means that before the pandemic, gold was declining. In addition, before the pandemic, USD/IDR volatility has the highest average (1.002575) compare to the other volatility variables but it has the least standard deviation (0.029098). contrary to that, gold volatility has the least average (0.877407) but highest standard deviation (0.244151)

During the pandemic, JCI return average is -0.1591 and the standard deviation is 0.021749 which means that during the outbreak of COVID-19, JCI return experienced a slump and had the highest risk compare to the other return variables. Other than that, USD/IDR return ( 0.3080 percent) has higher average than gold return ( 0.0482 percent) but at the same time USD/IDR also riskier than gold since USD/IDR return has higher standard deviation than gold return $(0.020244>0.015774)$. Additionally, during the pandemic, JCI volatility has the least average (0.847991) and the least standard deviation (0.261355) which makes it the least risky compare to the other volatility variables. While gold volatility has the highest standard deviation during the pandemic period which makes it the riskiest $(0.738142)$.

Overall, from January 2019 through August 2020, it is stated in the table that JCI return still experience a decline with high risk since the value of JCI return average is 0.0289 percent and it has the highest standard deviation (0.013110) compare to the other return variables. However, it is shown in the table as well that even if gold has the least return (average: 0.000031), the risk is lower compare to the other return variables (gold return's standard deviation: 0.010100). Besides that, from January 2019 through August 2020, USD/IDR volatility has the highest average (1.002917) and standard deviation (0.192787). while JCI volatility has the least average (0.998598) and gold volatility has the least standard deviation (0.047726).

\section{Unit Root Test Result}

Unit root test is done by using the Augmented-Dickey Fuller (ADF) test with 1\% $(0.01)$ as the critical value $(\alpha)$. There are three data that are tested by using ADF test, which are; before pandemic, during pandemic, and the combination of before and during pandemic (January 2019 to August 2020). The data will be accepted if the probability is lower than the critical value $(\alpha) \rightarrow($ probability $<\alpha)$. 
Table 1. Descriptive statistic of JCI, USD/IDR, and Gold

\begin{tabular}{clccccc}
\hline Period & \multicolumn{1}{c}{ Variable } & N & Minimum & Maximum & Mean & Dev. Std. \\
\hline \multirow{4}{*}{$\begin{array}{c}\text { Before } \\
\text { Pandemic }\end{array}$} & JCI return & 92 & -0.031567 & 0.030389 & 0.000207 & 0.009871 \\
& Gold return & 92 & -0.016578 & 0.012530 & -0.000183 & 0.005773 \\
& USD/IDR return & 92 & -0.027882 & 0.035921 & 0.001986 & 0.009787 \\
\cline { 2 - 7 } & JCI volatility & 92 & 0.959912 & 1.179364 & 0.999814 & 0.040987 \\
& Gold volatility & 92 & 0.499427 & 1.573370 & 0.877407 & 0.244151 \\
& USD/IDR volatility & 92 & 0.962431 & 1.116880 & 1.002575 & 0.029098 \\
\hline \multirow{5}{*}{ During } & JCI return & 92 & -0.117553 & 0.047632 & -0.001591 & 0.021749 \\
Pandemic & Gold return & 92 & -0.065626 & 0.037828 & 0.000482 & 0.015774 \\
& USD/IDR return & 92 & -0.046310 & 0.111927 & 0.003080 & 0.020244 \\
\cline { 2 - 7 } & JCI volatility & 92 & 0.298807 & 1.301512 & 0.847991 & 0.261355 \\
& Gold volatility & 92 & 0.458364 & 4.785310 & 1.001103 & 0.738142 \\
& USD/IDR volatility & 92 & 0.464979 & 1.702284 & 1.150550 & 0.351300 \\
\hline \multirow{3}{*}{$\begin{array}{c}\text { January 2019 } \\
\text { to August }\end{array}$} & JCI return & 393 & -0.065787 & 0.101906 & -0.000289 & 0.013110 \\
2020 & Gold return & 393 & -0.036995 & 0.046847 & 0.000031 & 0.010100 \\
& USD/IDR return & 393 & -0.046310 & 0.059477 & 0.001153 & 0.011160 \\
\cline { 2 - 6 } & JCI volatility & 393 & 0.305777 & 1.207040 & 0.998598 & 0.150452 \\
& Gold volatility & 393 & 0.710911 & 1.051697 & 1.000453 & 0.047726 \\
& USD/IDR volatility & 393 & 0.279363 & 1.259328 & 1.002917 & 0.192787 \\
\hline
\end{tabular}

As stated on the Table 2 below, it is shown that the data have a significant effect, since the probability of the data are lower than $(0.0000<0.01)$. Thus, the data pass the unit root test and can be used for the next test.

Table 2. Unit Root Test result

\begin{tabular}{|c|c|c|c|}
\hline Period & Variable & t-statistic & Probability \\
\hline \multirow{3}{*}{ Before Pandemic } & JCI & -10.00061 & $0.0000^{* \star *}$ \\
\hline & Gold & -9.173578 & $0.0000^{\text {tht }}$ \\
\hline & USD/IDR & -9.999588 & $0.0000^{\text {*t* }}$ \\
\hline \multirow{3}{*}{ During Pandemic } & JCI & -7.370486 & $0.0000^{* \star *}$ \\
\hline & Gold & -9.144801 & $0.0000^{* * *}$ \\
\hline & USD/IDR & -10.77823 & $0.0000^{* * *}$ \\
\hline \multirow{3}{*}{$\begin{array}{c}\text { January } 2019 \text { to } \\
\text { August } 2020\end{array}$} & $\mathrm{JCI}$ & -18.07053 & $0.0000^{\star \star \star \star}$ \\
\hline & Gold & -18.79775 & $0.0000^{* * *}$ \\
\hline & USD/IDR & -27.47536 & $0.0000^{\star * *}$ \\
\hline
\end{tabular}

${ }^{* * *}$ significant at the level of $1 \%$ significance

\section{Normality Test Result}

In conducting a financial market analysis, data abnormalities and heteroscedasticity problems are inevitable. And according to Mohd Nor \& Shamiri (2007), data with thick tails (leptokurtic) commonly are not fully portrayed by normal GARCH method. Furthermore, Yaya et al., (2014) added that t-student and Generalized Error Distribution (GED) of GARCH method are proven well to analyze the financial data with abnormality.

The normality test is done by using Jarque-Bera test and used to know which GARCH distribution is the most suitable for the analysis. Table 3 presents the result of normality test of the data. There are two GARCH distribution that will be used for this research. Gaussian (normal) distribution will be used for data which are normal, while GED distribution is applied for data with abnormalities since GED can represent the skewness and kurtosis of the Value-at-Risk appropriately. 
Table 3. Normality Test

\begin{tabular}{clcl}
\hline Variables & \multicolumn{1}{c}{ Period } & Probability & \multicolumn{1}{c}{ Conclusion } \\
\hline \multirow{2}{*}{ JCI, Gold, and } & Before pandemic & 0.000063 & Not normally distributed \\
USD/IDR return & During pandemic & 0.220477 & Normally distributed \\
& January 2019-August 2020 & 0.000019 & Not normally distributed \\
\hline \multirow{2}{*}{ JCI return, Gold and } & Before pandemic & 0.955763 & Normally distributed \\
USD/IDR Volatility & During pandemic & 0.004894 & Not normally distributed \\
& January 2019-August 2020 & 0.000006 & Not normally distributed \\
\hline \multirow{2}{*}{ JCI volatility, Gold } & Before pandemic & 0.029802 & Not normally distributed \\
and USD/IDR Return & During pandemic & 0.005461 & Not normally distributed \\
& January 2019-August 2020 & 0.000000 & Not normally distributed \\
\hline \multirow{2}{*}{ JCI, Gold, and } & Before pandemic & 0.000000 & Not normally distributed \\
USD/IDR volatility & During pandemic & 0.383591 & Normally distributed \\
& January 2019-August 2020 & 0.000000 & Not normally distributed \\
\hline
\end{tabular}

\section{GARCH Analysis Result}

Table 4 shows the GARCH result of gold and USD/IDR return impact on JCI return. Based on the table, the GARCH probability of all period are lower than the critical value $(5 \%)$ which means that the research model goes along with GARCH pattern. Furthermore, it can be seen that the probabilities of all independent data are exceeding all three-significance level $(1 \%, 5 \%, 10 \%)$. Therefore, it is concluded that there is no effect between gold, USD/IDR, and JCI return in all three periods (before pandemic, during pandemic, and the combination of before and during pandemic).

Table 4. The result of GARCH $(1,1)$ : The Impact of Gold and USD/IDR Return towards JCI Return

\begin{tabular}{|c|c|c|c|c|c|}
\hline \multirow{2}{*}{ Period } & \multirow{2}{*}{$\begin{array}{c}\text { Independent } \\
\text { Variable } \\
\end{array}$} & \multirow{2}{*}{ z-statistic } & \multirow{2}{*}{ Probability } & \multicolumn{2}{|c|}{ GARCH } \\
\hline & & & & z-Statistic & Probability \\
\hline \multirow{3}{*}{ Before Pandemic } & USD/IDR & 0.139524 & 0.8890 & \multirow{3}{*}{2.096576} & \multirow{3}{*}{$\begin{array}{l}0.0360 * * \\
(\mathrm{GED})\end{array}$} \\
\hline & Gold & -0.613897 & 0.5393 & & \\
\hline & C & 0.871169 & 0.3837 & & \\
\hline \multirow{3}{*}{ During Pandemic } & USD/IDR & 1.421079 & 0.1553 & \multirow{3}{*}{10.57307} & \multirow{3}{*}{$\begin{array}{c}0.0000^{* * *} \\
\text { (Gaussian) }\end{array}$} \\
\hline & Gold & 0.605623 & 0.5448 & & \\
\hline & $\mathrm{C}$ & -0.096223 & 0.9233 & & \\
\hline \multirow{3}{*}{$\begin{array}{c}\text { January } 2019 \text { to } \\
\text { August } 2020\end{array}$} & USD/IDR & 0.703220 & 0.4819 & \multirow{3}{*}{12.39478} & \multirow{3}{*}{$\begin{array}{l}0.0000^{* * *} \\
(\mathrm{GED})\end{array}$} \\
\hline & Gold & -1.002100 & 0.3163 & & \\
\hline & C & 1.286423 & 0.1983 & & \\
\hline
\end{tabular}

*** significant at the level of $1 \%$ significance

** significant at the level of $5 \%$ significance

In the Table 5, the result of GARCH analysis for gold return, USD/IDR return and JCI volatility is presented. Before the pandemic (January 2019-August 2019), it is shown that USD/IDR return affects the JCI volatility but gold does not. Nevertheless, needed to be underlined that the before pandemic data do not follow the GARCH pattern since the probability violate the significance level. Moreover, the result of the data from January 2019 to August 2020 also do not follow the GARCH pattern. However, the figure in the table reveal that there is no relation between gold return, USD/IDR return, and JCI volatility. Other than that, during the pandemic, both gold and USD/IDR return do not affect the JCI volatility since the probabilities of both independent data are greater than the all three-significance level. 
Table 5. The Result of GARCH $(1,1)$ : The Impact of Gold and USD/IDR Return towards JCI Volatility

\begin{tabular}{|c|c|c|c|c|c|}
\hline \multirow[b]{2}{*}{ Period } & \multirow{2}{*}{$\begin{array}{c}\text { Independent } \\
\text { Variable }\end{array}$} & \multirow{2}{*}{ z-statistic } & \multirow{2}{*}{ Probability } & \multicolumn{2}{|c|}{ GARCH } \\
\hline & & & & z-Statistic & Probability \\
\hline \multirow{3}{*}{ Before Pandemic } & USD/IDR & 3.316585 & $0.0009^{* * *}$ & \multirow{3}{*}{-0.231869} & \multirow{3}{*}{$\begin{array}{l}0.8166 \\
(\mathrm{GED})\end{array}$} \\
\hline & Gold & 0.604600 & 0.5454 & & \\
\hline & C & 15792529 & $0.0000^{* \star * *}$ & & \\
\hline \multirow{3}{*}{ During Pandemic } & USD/IDR & -0.246337 & 0.8054 & \multirow{3}{*}{14.93677} & \multirow{3}{*}{$\begin{array}{c}0.0000^{* * *} \\
(\mathrm{GED})\end{array}$} \\
\hline & Gold & 0.063519 & 0.9494 & & \\
\hline & C & 20.65926 & $0.0000^{* * *}$ & & \\
\hline \multirow{3}{*}{$\begin{array}{l}\text { January } 2019 \text { to } \\
\text { August } 2020\end{array}$} & USD/IDR & 0.738013 & 0.4605 & \multirow{3}{*}{0.149313} & \multirow{3}{*}{$\begin{array}{l}0.8813 \\
\text { (GED) }\end{array}$} \\
\hline & Gold & -1.243016 & 0.2139 & & \\
\hline & C & 342.8735 & $0.0000^{* * *}$ & & \\
\hline
\end{tabular}

${ }^{* * *}$ significant at the level of $1 \%$ significance

The result of relation between gold volatility, USD/IDR volatility, and JCI return is presented in Table 6 . Before and during the pandemic, it is shown that gold volatility has a positive impact while USD/IDR volatility has a negative impact on JCI return. Before the pandemic, the independent data are significant at the level of $1 \% ; 5 \%$; and $10 \%$. While during the pandemic, gold is significant at the level of $10 \%$ and USD/IDR is significant at the level of 5\% and 10\%. But somehow, table 6 shows that on January 2019 to August 2020, gold and USD/IDR volatility do not have any impact on JCI return as the probability of independent data are greater than the significance level.

Table 6. The Result of GARCH $(1,1)$ : The Impact of Gold and USD/IDR Volatility towards JCI Return

\begin{tabular}{|c|c|c|c|c|c|}
\hline \multirow{2}{*}{ Period } & \multirow{2}{*}{$\begin{array}{c}\text { Independent } \\
\text { Variable }\end{array}$} & \multirow{2}{*}{ z-statistic } & \multirow{2}{*}{ Probability } & \multicolumn{2}{|c|}{ GARCH } \\
\hline & & & & z-Statistic & Probability \\
\hline \multirow{3}{*}{$\begin{array}{c}\text { Before } \\
\text { Pandemic }\end{array}$} & USD/IDR & -116.1721 & $0.0000^{* \text { *t* }}$ & \multirow{3}{*}{15.54013} & \multirow{3}{*}{$\begin{array}{c}0.0000^{* * *} \\
\text { (Gaussian) }\end{array}$} \\
\hline & Gold & 942.4847 & $0.0000^{*+*+*}$ & & \\
\hline & $\mathrm{C}$ & -14.85572 & $0.0000^{\text {*t* }}$ & & \\
\hline \multirow{3}{*}{$\begin{array}{l}\text { During } \\
\text { Pandemic }\end{array}$} & USD/IDR & -2.290453 & $0.0220^{* *}$ & \multirow{3}{*}{6.342266} & \multirow{3}{*}{$\begin{array}{c}0.0000^{* \star *} \\
(\text { GED) }\end{array}$} \\
\hline & Gold & 1.815952 & $0.0694^{*}$ & & \\
\hline & C & 1.222748 & 0.2214 & & \\
\hline \multirow{3}{*}{$\begin{array}{c}\text { January } 2019 \text { to } \\
\text { August } 2020\end{array}$} & USD/IDR & 0.068360 & 0.9455 & \multirow{3}{*}{12.95542} & \multirow{3}{*}{$\begin{array}{l}0.0000^{* *+*} \\
(\mathrm{GED})\end{array}$} \\
\hline & Gold & -0.214575 & 0.8301 & & \\
\hline & C & 0.248738 & 0.8036 & & \\
\hline
\end{tabular}

${ }^{* * *}$ significant at the level of $1 \%$ significance

**significant at the level of $5 \%$ significance

"significant at the level of $10 \%$ significance

Table 7 presented the GARCH analysis result for gold, USD/IDR, and JCI volatility. According to the table, USD/IDR and gold volatility are affecting the JCI volatility in all three periods. Before the pandemic, both independent data (USD/IDR and gold volatility) positively affect the JCI volatility. Furthermore, USD/IDR and gold volatility also show a positive relation with JCI volatility on January 2019 to August 2020. However, it is shown in the Table 7 as well, that during the outbreak of COVID-19, gold volatility has a negative impact while USD/IDR volatility has a positive impact on JCI volatility as it is known that the probabilities of the independent data are lower than the significance level $(1 \% ; 5 \% ; 10 \%)$ and the $z$-statistic result for gold volatility has a negative value and z-statistic of USD/IDR volatility has a positive value. 
Table 7. The Result of GARCH (1,1): The Impact of Gold and USD/IDR Volatility towards JCI Volatility

\begin{tabular}{|c|c|c|c|c|c|}
\hline \multirow{2}{*}{ Period } & \multirow{2}{*}{$\begin{array}{c}\text { Independent } \\
\text { Variable }\end{array}$} & \multirow{2}{*}{ z-statistic } & \multirow{2}{*}{ Probability } & \multicolumn{2}{|c|}{ GARCH } \\
\hline & & & & z-Statistic & Probability \\
\hline \multirow{3}{*}{$\begin{array}{c}\text { Before } \\
\text { Pandemic }\end{array}$} & USD/IDR & 11.50295 & $0.0000^{* *+k}$ & \multirow{3}{*}{-2.863444} & \multirow{3}{*}{$\begin{array}{c}0.0042^{* * *} \\
(\mathrm{GED})\end{array}$} \\
\hline & Gold & 19.21534 & $0.0000^{* * *}$ & & \\
\hline & C & -3.319721 & $0.0009^{*+k+1}$ & & \\
\hline \multirow{3}{*}{$\begin{array}{l}\text { During } \\
\text { Pandemic }\end{array}$} & USD/IDR & 26.74739 & $0.0000^{* *+*}$ & \multirow{3}{*}{2.092088} & \multirow{3}{*}{$\begin{array}{c}0.0364^{* *} \\
\text { (Gaussian) }\end{array}$} \\
\hline & Gold & -3.038159 & $0.0024^{* \star *}$ & & \\
\hline & C & 20.91464 & $0.0000^{* *+1}$ & & \\
\hline \multirow{3}{*}{$\begin{array}{l}\text { January } 2019 \text { to } \\
\text { August } 2020\end{array}$} & USD/IDR & 11.50295 & $0.0000^{* \text { *t+ }}$ & \multirow{3}{*}{-2.863444} & \multirow{3}{*}{$\begin{array}{l}0.0042^{\text {*** }} \\
(\mathrm{GED})\end{array}$} \\
\hline & Gold & 19.21534 & $0.0000^{* * *+}$ & & \\
\hline & C & -3.319721 & $0.0009^{* * * *}$ & & \\
\hline
\end{tabular}

${ }^{* * *}$ significant at the level of $1 \%$ significance

**significant at the level of $5 \%$ significance

\section{DISCUSSION}

From the GARCH analysis of table 4, it is shown that either gold nor USD/IDR return do not affect the JCI return in all periods of analysis. This means, overall, gold and USD/IDR return do not have any relation with JCI return from January 2019 through August 2020. Secondly, on the table 5, the GARCH analysis shows that gold return does not have any relation with JCI volatility in all periods. While, USD/IDR return positively affected JCI volatility only before the outbreak of COVID-19 happened in Indonesia. However, USD/IDR return and JCI volatility do not have any relation in the period of the COVID-19 pandemic. Thirdly, table 6 discuss about the impact of gold and USD/IDR volatility towards JCI return. It is shown that during the COVID-19 pandemic there is no relation between gold volatility, USD/IDR volatility and JCI return. However, it is stated on the table 6 as well that before the outbreak of COVID-19, gold volatility positively affected JCI return and USD/IDR volatility negatively affected JCI return. this implies that the more volatile the gold return is, the higher the JCI return. While the more volatile the USD/IDR return is, the lower the JCI return will be, vice versa. Yet overall, from January 2019 through August 2020, gold and USD/IDR volatility do not have any effect towards JCI return.

The first hypothesis is proven by the analysis of USD/IDR volatility and JCI volatility during the outbreak of COVID-19 in Table 7. As stated in Table 7, USD/IDR volatility positively affects JCI volatility during COVID-19 pandemic (January 2020August 2020). In addition, USD/IDR and JCI volatility also shows the same reaction before the pandemic (January 2019-August 2020). Thus, it can be concluded that in the presence or absence of COVID-19 pandemic, USD/IDR volatility will still positively affect JCI volatility. This means, as the foreign exchange rises, the JCI volatility will increase as well, vice versa. This result is in line with Surbakti et al., (2016) analysis which stated that exchange rate and JCI volatility have a positive impact during global financial turmoil. Other researches, such as Pinjaman \& Aralas (2015) and Kalu \& Okwuchukwu (2014) also approved that exchange rate and stock volatility have positive relations. Additionally, Endri, Abidin, Simanjuntak, \& Nurhayati (2020) analyzed macroeconomic variables, international stock exchanges, and JCI volatility from January 2012 through December 2018 using GARCH method and found that exchange rate also positively and significantly affected JCI volatility. 
Exchange rate and JCI volatility are happened to have a positive relation because during the COVID-19 outbreak, Indonesia's economy was in a bad condition and the IDR value depreciated against USD value. Therefore, many companies in Indonesia faced a difficulty in paying imported supplies and external debt which caused reduction in profit. This phenomenon led to the decrease of investors' interest in funding the companies. Thus, the companies' stock price will drop and eventually affect the JCI movement (Robiyanto et al., 2019). In addition, as the foreign investors saw that Indonesia was in an economy crisis during the pandemic, many of them start to withdraw their investment money which cause the drop of stock market inflow and thus, JCI volatility is inescapable.

The second hypothesis concerning the relation of gold and JCI volatility during COVID-19 pandemic in Table 7 is shown to be accepted. It is stated in the table that during the outbreak of COVID-19 (January 2020-August 2020), gold volatility negatively affected JCI volatility. Whereas Surbakti et al., (2016) and Syahri \& Robiyanto (2020) results show that during the economy crisis, gold and JCI volatility do not have any significant relation. However, Miyazaki \& Hamori (2013) confirmed that during the economic crisis, assets that are usually used for save haven or hedging investment generally have a negative relation or even do not have any relation with the other assets. Additionally, gold and JCI volatility are found negatively related only during the outbreak of COVID-19, as it is shown in Table 7 that before the pandemic (January 2019August 2019) gold and JCI volatility are positively related. Which means that the more volatile the gold price is, the more volatile the JCI return.

In the pandemic situation like COVID-19 outbreak, many investors start looking for other investments to reduce their risk, this statement is in line with Prawirosaputro \& Hapsari (2017) analysis which stated that during the critical financial market turmoil, a lot of investors will start looking for the real assets (i.e. gold) to be invested, as the stock return or bonds are no longer capable in enduring the risk. During the economy crisis, many investors will start varying their portfolio and invest for hedging or save haven assets. Gold is proven to be one of the hedging tactics or save haven assets during the financial turmoil (Cohen \& Qadan, 2010; Ibrahim \& Baharom, 2011; Robiyanto et al., 2017). Furthermore, Ji, Zhang, \& Zhao (2020) conducted a study relating the save haven asset in the outbreak of COVID-19 and found that during the pandemic, gold can be used as safe-haven investment in emerging countries.

\section{CONCLUSION, LIMITATIONS, AND SUGGESTIONS}

The purpose of this study is to find the relation between USD/IDR, gold, and JCI volatility during the outbreak of COVID-19 in Indonesia. The analysis uses GARCH method and time-series data which consist of before pandemic (January 2019-August 2019), during pandemic (January 2020-August 2020), and the combination of before pandemic and during pandemic period (January 2019-August 2020). It is concluded from the result that USD/IDR volatility has a positive effect towards JCI volatility, while gold volatility negatively affects JCI volatility during the COVID-19 pandemic in Indonesia. This phenomenon happened because during the pandemic, Indonesia faced the economy crisis where many companies and industries had a difficulty in importing raw materials and paying foreign debts which makes the investors disinterested in investing their money in the stock market of Indonesia. This finding also supports the arbitrage pricing theory which has existed based on an empirical data and prove the concept of gold as a safe haven is a robust concept. Additionally, knowing that Indonesia had an economy 
crisis also made the foreign investors withdraw their money from Indonesia's stock market and therefore, will affect the JCI volatility. Furthermore, since many investors know that Indonesia faced a financial turmoil during the outbreak of COVID-19, they started looking for a safe haven or hedging investment to reduce their risk investment. Based on this analysis and previous studies, it is proven that gold can be used as an investment during the financial turmoil.

However, considering the fact that the outbreak of COVID-19 did not only affect the economy in Indonesia, but also the economy around the world. Therefore, further analysis from the other countries are also needed since there might be different result from each country to another. In this case, since Indonesia is considered as one of the developing countries, the analysis of the determinant of stock market volatility during the outbreak of COVID-19 might be different with the developed countries. Moreover, further research is also needed to analyze the determinant of JCI volatility from the beginning until the end of COVID-19 pandemic in Indonesia seeing that until this research is finished, the COVID-19 pandemic is still happening in Indonesia. In addition, the next researcher can add more independent variables such as interest rate, bonds, etc. in order to know how it impacts to the Indonesia's economy. Other than that, the GARCH probability for the analysis of USD/IDR return, gold return and JCI volatility before the pandemic and in the period of January 2019 through August 2020 have a greater value compare to the significant value which makes it does not follow the GARCH pattern.

\section{REFERENCES}

Abd Rahman, R., \& Ramli, R. (2012). The Effect of Macroeconomic Variables on Stock Price Volatility: Evidence from Jakarta Composite Index, Agriculture, and Basic Industry Sector. International Proceedings of Economics Development and Research, 46, 96-100. https://doi.org/10.7763/IPEDR

Adam, P. (2014). Statistical Characteristics of Jakarta Composite Index (JCI) Dynamics Based on Short Term Data Represented in Candles. International Journal of Economics, Finance and Management Sciences, 2(2), 138-142. https://doi.org/10.11648/j.ijefm.20140202.14

Al-Awadhi, A. M., Alsaifi, K., Al-Awadhi, A., \& Alhammadi, S. (2020). Death and Contagious Infectious Diseases: Impact of the COVID-19 Virus on Stock Market Returns. Journal of Behavioral and Experimental Finance, 27, 2-5. https:// doi.org/10.1016/j.jbef.2020.100326

Baker, S. R., Bloom, N., Davis, S. J., Kost, K. J., Sammon, M. C., \& Viratyosin, T. (2020). The Unprecendeted Stock Market Impact of COVID-19. National Bureau of Economic Research, 26945, 1689-1699. https://marcosammon.com/images/StockMarkets_COVID.pdf

Baur, D. G., \& Lucey, B. M. (2010). Is Gold a Hedge or a Safe Haven? An Analysis of Stocks, Bonds and Gold. Financial Review, 45(2), 217-229. https://doi.org/10.1111/j.1540-6288.2010.00244.x 
Baur, D. G., \& McDermott, T. K. (2010). Is Gold a Safe Haven? International Evidence. Journal of Banking and Finance, 34(8), 1886-1898. https://doi.org/10.1016/j.jbankfin.2009.12.008

Bollerslev, T. (1986). Generalized Autoregressive Conditional Heteroskedasticity. Journal of Econometrics, 31(3), 307-327. https:/ / doi.org/10.1109/TNN.2007.902962

Chandra, C. E. (2020). Reaching New Equilibrium of Rupiah: How It Can be Weaker by COVID-19? Research Gate, 2, 2-9. https://doi.org/10.13140/RG.2.2.34693.09444

Cohen, G., \& Qadan, M. (2010). Is Gold Still a Shelter to Fear? American Journal of Social and Management Sciences, 1(1), 39-43. https:// doi.org/10.5251/ajsms.2010.1.1.39.43

Daly, K. (2011). An Overview of the Determinants of Financial Volatility: An Explanation of Measuring Techniques. Modern Applied Science, 5(5), 46-63. https://doi.org/10.5539/mas.v5n5p46

Endri, E., Abidin, Z., Simanjuntak, T. P., \& Nurhayati, I. (2020). Indonesian Stock Market Volatility: GARCH Model. Montenegrin Journal of Economics, 16(2), 7-17. https://doi.org/10.14254/1800-5845/2020.16-2.1

Engle. (1982). Autoregressive Conditional Heteroscedacity with Estimates of variance of United Kingdom Inflation,journal of Econometrica, Volume 50, Issue 4 (Jul., 1982),987-1008. In Econometrica (Vol. 50, Issue 4, pp. 987-1008). https://doi.org/10.2307/1912773

Engle, R. F. (1983). Estimates of the Variance of U.S. Inflation Based upon the ARCH Model. Journal of Money, Credit and Banking, 15(3), 286. https:// doi.org/10.2307/1992480

Handayani, H., Muharam, H., Mawardi, W., \& Robiyanto, R. (2018). Determinants of the Stock Price Volatility in the Indonesian Manufacturing Sector. International Research Journal of Business Studies, 11(3), 179-193. https://doi.org/10.21632/irjbs.11.3.179193

Huang, C., Wang, Y., Li, X., Ren, L., Zhao, J., Hu, Y., Zhang, L., Fan, G., Xu, J., Gu, X., Cheng, Z., Yu, T., Xia, J., Wei, Y., Wu, W., Xie, X., Yin, W., Li, H., Liu, M., ... Cao, B. (2020). Clinical Features of Patients Infected with 2019 Novel Coronavirus in Wuhan, China. The Lancet, 395(10223), 497-506. https://doi.org/10.1016/S01406736(20)30183-5

Hussin, M. Y. M., Muhammad, F., Razak, A. A., Tha, G. P., \& Marwan, N. (2013). The Link Between Gold Price, Oil Price and Islamic Stock Market: Experience from Malaysia. Journal of Studies in Social Sciences, 4(2), 161-182. https://www.researchgate.net/publication/306536880 
Ibrahim, M. H., \& Baharom, A. H. (2011). The Role of Gold in Financial Investment: A Malaysian Perspective. Economic Computation and Economic Cybernetics Studies and Research, 45(4), 227-238. http://www.ecocyb.ase.ro/nr4

Ji, Q., Zhang, D., \& Zhao, Y. (2020). Searching for Safe-Haven Assets during the COVID19 Pandemic. International Review of Financial Analysis, 71(May), 101526. https://doi.org/10.1016/j.irfa.2020.101526

Kalu, E., \& Okwuchukwu, O. (2014). Stock Market Return Volatility and Macroeconomic Variables in Nigeria. International Journal of Empirical Finance, 2(2), 75-82. https://www.academia.edu/download/33870332/Paper_3.pdf

Karali, B., \& Power, G. J. (2010). Commodity Price Volatility and the Economic Uncertainty of Pandemic. The Rimini Centre for Economic Analysis (RCEA), 20(12), 114. https:// papers.ssrn.com/sol3/papers.cfm?abstract_id=3581193

Karmakar, M. (2005). Modeling Conditional Volatility of the Indian Stock Markets. Vikalpa, 30(3), 21-37. https:// doi.org/10.1177/0256090920050303

Kirui, E., Wawire, N. H. W., \& Onono, P. O. (2014). Macroeconomic Variables, Volatility and Stock Market Returns: A Case of Nairobi Securities Exchange, Kenya. International Journal of Economics and Finance, 6(8), 214-228. https://doi.org/10.5539/ijef.v6n8p214

Kishor, N., \& Singh, R. P. (2016). Stock Return Volatility Effect: Study of BRICS. Transnational Corporations Review, 6(4), 406-418. https:/ / doi.org/10.5148/tncr.2014.6406

Liu, H., Manzoor, A., Wang, C., Zhang, L., \& Manzoor, Z. (2020). The COVID-19 Outbreak and Affected Countries Stock Markets Response. International Journal of Environmental Research and Public Health, 17(8), 1-19. https://doi.org/10.3390/ijerph17082800

Miyazaki, T., \& Hamori, S. (2013). Testing for Causality Between the Gold Return and Stock Market Performance: Evidence for "Gold Investment In Case of Emergency." Applied Financial Economics, 23(1), 27-40. https:/ / doi.org/10.1080/09603107.2012.699184

Mohd Nor, A. H. S., \& Shamiri, A. (2007). Modeling and forecasting volatility of the Malaysian and the Singporean stock indices using asymmetric GARCH models and non-normal densities. Malaysian Journal of Mathematical Sciences, 1(1), 83-102. https://einspem.upm.edu.my/jurnal/index.php/mjms/article/view/15

Naryono, E., \& Sukabumi, S. (2020). Impact of National Disaster Covid-19, Indonesia Towards Economic Recession. Center for Open Science, 5(3), 1-10. https://osf.io/preprints/5cj3d/ 
Nia, V. M. (2020). The Effect of Corona Outbreak on the Indonesian Stock Market. American Journal of Humanities and Social Sciences Research (AJHSSR), 4(3), 358-370. https://www.ajhssr.com/wp-content/uploads/2020/03/ZU2043358370.pdf

Olweny, \& Omondi. (2011). The Effect of Macro-Economic Factors on Stock Return Volatility in the Nairobi Stock Exchange, Kenya. Economics and Finance Review, 1(10), 34-48. http://www.businessjournalz.org/efr

Pandey, A. (2005). Volatility Models and Their Performance in Indian Capital Markets. Vikalpa, 30(2), 27-46. https:/ / doi.org/10.1177/0256090920050203

Pantas, P. E., Ryandono, M. N. H., Munir, M., \& Wahyudi, R. (2019). Cointegration of Stock Market and Exchange Rate in Indonesia. Ihtifaz: Journal of Islamic Economics, Finance, and Banking, 2(2), 125. https://doi.org/10.12928/ijiefb.v2i2.886

Pinjaman, S. Bin, \& Aralas, S. B. (2015). The Dynamic Stock Returns Volatility and Macroeconomic Factors in Malaysia: A Sectoral Study. South East Asia Journal of Contemporary Business, Economics and Law, Vol. 8, 8(3), 33-40. https://www.researchgate.net/publication/335791067

Prawirosaputro, B., \& Hapsari, Y. D. (2017). The Effects of Rupiah Currency, World Oil Prices, and World Gold Price on Composited Stock Price Index (IHSG) in 2016. Jurnal Manajemen, 14(2), 144-151. https:// doi.org/10.25170/jm.v14i2.784

Putra, A. R., \& Robiyanto, R. (2019). The Effect of Commodity Price Changes and USD/IDR Exchange Rate on Indonesian Mining Companies' Stock Return. Jurnal Keuangan Dan Perbankan, 23(1), 97-108. https:/ / doi.org/10.26905/jkdp.v23i1.2084

Rashid Sabri, N. (2004). Stock Return Volatility and Market Crisis In Emerging Economies. Review of Accounting and Finance, 3(3), 59-83. https://doi.org/10.1108/eb043408

Robiyanto, R. (2018). The Effect of Gold Price Changes, USD/IDR Exchange Rate Changes and Bank Indonesia (BI) Rate on Jakarta Composite Index (JCI)'S Return and Jakarta Islamic Index (JII)'S Return. Jurnal Manajemen Dan Kewirausahaan, 20(1), 45. https://doi.org/10.9744/jmk.20.1.45-52

Robiyanto, R., Santoso, M. A., Atahau, A. D. R., \& Harijono, H. (2019). The Indonesia Stock Exchange and Its Dynamics: An Analysis of the Effect of Macroeconomic Variables. Montenegrin Journal of Economics, 15(4), 59-73. https://doi.org/10.14254/1800-5845/2019.15-4.5

Robiyanto, R., Wahyudi, S., \& Pangestuti, I. R. D. (2017). The Volatility-Variability Hypotheses Testing and Hedging Effectiveness of Precious Metals for the Indonesian and Malaysian Capital Markets. Gadjah Mada International Journal of Business, 19(2), 167-192. https:/ /doi.org/10.22146/gamaijb.26260 
Sansa, N. A. (2020). The Impact of the Covid-19 on the Financial Markets: Evidence from China and USA. Electronic Research Journal of Social Sciences and Humanities, 2(2), 2939. https:// papers.ssrn.com/sol3/papers.cfm?abstract_id=3567901

Senol, Z., \& Zeren, F. (2020). Coronavirus (COVID-19) and Stock Markets: The Effects of the Pandemic on the Global Economy. Eurasian Journal of Researches in Social and Economics (EJRSE), 7(4), 1-16. https://www.researchgate.net/publication/341029980

Surbakti, E. H., Achsani, N. A., \& Maulana, T. N. A. (2016). The Impact of Macroeconomic Variables on JCI's Stock Return Volatility in Pre and Post Global Economic Crisis. International Journal of Scientific and Research Publications, 6(3), 213-220. https://pdfs.semanticscholar.org/c64d/66c315946989731e3fb0e322a45b70ddf93c.p df

Syahri, A., \& Robiyanto, R. (2020). The Correlation of Gold, Exchange Rate, and Stock Market on COVID-19 Pandemic Period. Jurnal Keuangan Dan Perbankan, 24(3), 350362. https://doi.org/10.26905/jkdp.v24i3.4621

Temmuz, F. D., \& Oma, A. (2012). An Observation of the Relationship Between Gold Prices and Selected Financial Variables in Turkey. Muhasebe ve Finansman Dergisi, 55, 195-206. http://www.journal.mufad.org.tr/attachments/article/661/11.pdf

Vahlevi, T. M. R., \& Muharam, H. (2017). Quantitative Easing Program and Financial Market Volatility in Indonesia. Journal of Economics and Policy (Jejak), 10(1), 80-89. https://doi.org/10.15294/jejak.v10i1.9128

Wahyudi, R. N., Asdar, M., \& Nohong, M. (2017). The Influence of Macroeconomic Variables Toward Jakarta Composite Index on Indonesia Stock Exchange. Jurnal Bisnis, Manajemen Dan Informatika, 14(2), 131-148. https://doi.org/http://dx.doi.org/10.26487/jbmi.v14i2.2164

Walid, C., Chaker, A., Masood, O., \& Fry, J. (2011). Stock Market Volatility and Exchange Rates in Emerging Countries: A Markov-State Switching Approach. Emerging Markets Review, 12(3), 272-292. https:// doi.org/10.1016/j.ememar.2011.04.003

WHO South-East Asia. (2020). Global Update on Coronavirus Disease. WHO South-East Asia. https://www.who.int/indonesia/news/novel-coronavirus

World Health Organization. (2020). WHO Timeline - Covid-19. World Health Organization. https://www.who.int/news-room/detail/27-04-2020-who-timeline---covid-19

Yaya, O. O. S., Olubusoye, O. E., \& Ojo, O. O. (2014). Estimates and Forecasts of GARCH Model Under Misspecified Probability Distributions: A Monte Carlo Simulation Approach. Journal of Modern Applied Statistical Methods, 13(2), 479-492. https://doi.org/10.22237/jmasm/1414816020 
Zhang, D., Hu, M., \& Ji, Q. (2020). Financial Markets Under the Global Pandemic of COVID-19. Finance Research Letters, 10, 101-528. https://doi.org/10.1016/j.frl.2020.101528 